\title{
Entrepreneurial orientation in hotel establishments
}

\author{
Completed Research Paper
}

\author{
Felipe Hernández Perlines \\ University of Castilla-La Mancha \\ Felipe.HPerlines@uclm.es
}

\author{
Benito Yañez Araque \\ University of Castilla-La Mancha \\ Benito.Yanez@uclm.es
}

\begin{abstract}
The present paper analyses the influence of entrepreneurial orientation (integrated approach) and its dimensions (individual approach) on hotel performance. We pose a structural equation model (SEM) Partial Least Square (PLS) through Smart PLS 3.1.9 on a dataset obtained by means of a questionnaire emailed to 102 hotel directors between January and June 2014. The most relevant contribution of this work lies in the fact that the impact of entrepreneurial orientation in an integrated approach (the three dimensions acts jointly) exceeds the effect of each individual approach.
\end{abstract}

Keywords: Entrepreneurial orientation, Performance, Innovation, Proactiveness, RiskTaking, Hotel Establishments. 


\section{Introduction}

Increased competitiveness, market globalization and the influence of technology on business make entrepreneurial orientation a need for most firms (Tajeddini \& Trueman, 2008). Therefore, it becomes necessary to analyse how to: 1) take advantage of new opportunities; 2) develop new products/services and markets (Berthon et al., 2004); 3) develop proactive behaviours (Kreiser et al., 2013); and 4) take greater risks (Godwin \& Abaho, 2013). This has led numerous firms to place entrepreneurial orientation in the spotlight of their competitiveness. In this sense, recent years have witnessed the proliferation of studies on entrepreneurial orientation and its impact on firm performance (Basso et al., 2009; Rauch et al., 2009; Arzubiaga et al., 2012; Rodrigo-Alarcón et al., 2013; Hernández Perlines, 2014). It is true that the existing literature on entrepreneurial orientation is mainly based on knowledge acquired in the industry sector, works focused on the hotel sector being rather scarce (Tajeddini, 2010). The present work is aimed at making up this deficiency, given that hotels are one of the most important sectors worldwide. ${ }^{1}$

Different multidimensional constructs are used in entrepreneurial orientation, though we follow Miller's (1983) proposal, who considers that entrepreneurial orientation is integrated by the constant search for innovation, pro-activeness and predisposition to take moderate risks. Two approaches are applied in the present study for the analysis of entrepreneurial orientation: 1) the integrated or composite approach, in which the joint effect of the three dimensions that shape entrepreneurial orientation is analysed, and 2) the independent approach, in which the independent effect of each of these three dimensions is analysed separately (Dai et al., 2013). This is another innovative aspect in the present study, as two approaches are proposed in the same work to determine which one offers better explanatory capacity of hotel establishment performance.

Data were collected through a questionnaire answered by 102 2-to-5-star hotel directors across Spain taken from the directory in the Official Spain Hotel Guide published by Turespaña. Data were collected through a survey emailed between January and June 2014 to the directors of the aforementioned establishments. We pose a component-based structural equation model and PLS (partial least square) variance through software Smart PLS 3.1.9.

The proposed research provides guidelines for the management of hotel establishments: how hotel managers can improve their performance from the viewpoint of entrepreneurial orientation and its dimensions. Information is provided to get to know whether it is better to act jointly in its three dimensions (innovation, pro-activeness and risk-taking) or, on the contrary, it is better to act on each dimension independently.

The present paper is structured as follows: the main theoretical aspects of entrepreneurial orientation are analysed and the hypotheses to be contrasted are presented in the following section, where special attention is drawn on hotel establishments. Research design is explained next, as well as the questionnaire used, the field work completed, the sample and variable measurement. The fourth section is devoted to discussing results. Finally, conclusions and the most relevant future implications and present limitations are drawn and analysed.

\footnotetext{
${ }^{1}$ According to the Barometer of the World Tourism Organization, the volume of international tourists (visitors spending the night) in the whole world reached 1,100 millions in 2014 , thus undergoing $4.7 \%$ growth relative to the previous year. According to these sources, there are around 590,000 hotels in the world, with more than 29 million beds.
} 


\section{Theory and Hypothesis}

\subsection{Entrepreneurial orientation}

In the last years, entrepreneurial orientation has been widely studied in business literature, receiving considerable conceptual and empirical attention. Besides, it is an area with a fastgrowing accumulative corpus of knowledge (Basso et al., 2009; Rauch et al., 2009; Arzubiaga et al. 2012; Covin \& Miller, 2013; Rodrigo-Alarcón et al. 2013, Hernández Perlines, 2014).

Miller (1983) was the first to talk about entrepreneurial orientation and conceived it as firm behaviour characterised by innovation, pro-activeness and risk-taking. Later on, Covin \& Slevin (1989) completed Miller's definition stating that a firm's entrepreneurial orientation depends on the degree in which it favours change and innovation, taking risks and competing aggressively (Miller \& Friesen, 1983; Covin \& Slevin, 1991; Knight, 1997; Wiklund \& Shepherd, 2005).

On the other hand, Fazul et al. (2010) state that entrepreneurial orientation is the firm's capacity to perform innovation-related activities, take risks and pioneer new actions. Therefore, it is a decision making process (Patel \& D'Souza, 2009) that affects the firm's will to innovate, to be more pro-active and aggressive than its competitors, and to take risks (Ellis, 2011).

In this work we have followed Miller's (1983) definition of entrepreneurial orientation. According to him, entrepreneurial orientation is a multidimensional concept integrated by the constant search for innovation, pro-activeness and the will to take moderate risks. Innovation is referred to the firm's capacity to support new ideas and experimentation, to introduce new products, and to use creative processes (Miller \& Friesen, 1983; Kropp et al., 2006; Chandra et al. 2007). On the other hand, pro-activeness is referred to the search of the pioneer's advantage by means of anticipating the market's future desires and needs, and the capitalization of emerging business opportunities (Covin \& Slevin, 1989; Lumpkin \& Dess, 1996). In short, pro-activeness is the firm's capacity to involve resources, introducing new products and services before competitors do, according to predictions of future demand (Covin \& Slevin, 1991; Rauch et al., 2004; Sepulveda, 2010; Ma et al. 2012). Finally, risktaking entails setting off audacious actions involving significant resource levels (Lumpkin \& Dess, 1996).

The different existing multidimensional constructs of entrepreneurial orientation are just different perspectives of this concept (Covin \& Lumpkin, 2011). Thus, a set or works (among which Miller, 1983; Covin \& Slevin, 1989; and Covin \& Wales, 2012, stand out) state that for a firm to have entrepreneurial orientation, the aforementioned dimensions must covariate positively. On the contrary, another set of works (among which Lumpkin \& Dess, 1996; and Dai et al., 2013 stand out) state that each dimension of the entrepreneurial orientation plays a different role. We follow the first entrepreneurial-orientation construction in this paper: its three dimensions must covariate positively to give rise to entrepreneurial orientation.

Most research works are focused on analyzing the impact of entrepreneurial orientation on firm performance. Besides, entrepreneurial orientation is considered a fundamental organizational process (Hult et al., 2003) that contributes to reassure firm performance (Barringer \& Bluedorn, 1999; Dimitratos \& Plakoyiannaki, 2003; Hitt et al., 2001; McDougall \& Oviatt, 2000; and Miller, 1983). Taking this discussion into account, the following hypothesis is tested: 


\section{$H_{1}:$ Entrepreneurial orientation has a positive impact on hotel establishment performance}

\subsection{Innovation}

Innovation is "a firm's tendency to take part and support new ideas that may result in new products, services or technology processes" (Lumpkin \& Dess, 1996, p. 142). This tendency allows the firm to create a wide set of abilities that are an invaluable tool for competitiveness in the always changing business environment (Godwin \& Abaho, 2013).

Several works state that innovation, rather than any other dimension, is always present in every entrepreneurial process (Sharma \& Chrisman, 1999). Corporative entrepreneurial activities are aimed at taking advantage of market opportunities through innovation (Ireland et al., 2006). "Out of the different entrepreneurial-orientation dimensions identified in literature, innovation is, in a wide sense, an underlying factor shared by all forms of corporative entrepreneurial activity" (Covin \& Miller, 1999, p. 47).

Innovation demands such a display of resources that it will become profitable only when initial investments are compensated (Kreiser et al., 2013). In other words, the higher the innovation level is, the better the firm's results shall be. This leads us to formulate the following hypothesis:

\section{$\mathrm{H}_{2}:$ Innovation has a positive impact on hotel establishment performance}

\subsection{Proactiveness}

Pro-activeness reflects the firm's will to dominate its competitors by means of aggressive moves such as the introduction of new or innovative products or services, or the anticipation of future demands (Ke et al., 2007). This posture allows acting on the market's future shortcomings and potential needs, which creates a competitive advantage (Lumpkin \& Dess, 1996). In our work pro-activeness has been considered one of the dimensions of corporative entrepreneurial orientation, according to the existing literature on this issue. Thus, the following hypothesis is formulated:

\section{$H_{3}$ : Proactiveness has a positive impact on hotel establishment performance}

\subsection{Risk-taking}

Risk-taking behaviour is "incurring a large debt or compromising large amounts of resources with the aim of obtaining high returns when taking control of market opportunities" (Lumpkin \& Dess, 1996, p. 144).

Firms that are capable of assuming high risk levels are also capable of taking better advantage of opportunities and of obtaining higher long-term profit levels in a context of elevated uncertainty (McGrath, 2001). Authors such as Rauch et al. (2004) and Seyed (2012) state that risk-taking is positively related to performance.

\section{$H_{4}$ : Risk-taking has a positive effect on hotel establishment performance}




\section{Research Design}

\subsection{Questionnaire and field work}

Given the nature of this research and the inexistence of sources of secondary data, a questionnaire was elaborated for data collection purposes. We focused on hotel establishments located in Spain; therefore, the sample is homogeneous and allows controlling certain contingency factors (Rauch et al., 2009).

Questionnaire elaboration was completed in several stages. Firstly, a draft was made after reviewing literature on entrepreneurial orientation and firm performance. Secondly, to assure content validity, a discussion and reflection process was triggered among some experts in the aforementioned fields. Next, to guarantee that questionnaire items were fully understandable, a pre-test was completed with 2-to-5-star hotel establishment directors. Surveys were completed by means of personal interviews to each respondent. After this stage, questionnaire was emailed to hotel establishment directors. After a month's time, questionnaires were emailed again so as to increase the response rate (Dillman, 2000). The survey was completed between January and June 2014. The different dimensions were measured by means of 5point Likert scales $(1=$ complete disagreement; $5=$ full agreement $)$.

For hypothesis contrast and analysis of results, a structural equation multivariate model was used as a statistical technique. Bearing research objectives and hypotheses in mind, we opted for partial least squares (PLS) regression, which allows us to develop component- and variance-based analysis. PLS is a currently well-established technique for structural equation analysis used in a wide range of researches on organization and strategic management (Robins et al., 2002; Tsang, 2002). PLS takes a component-based approach for the estimation of the measurement model and the structural model; it is mainly aimed at predicting depending variables and allows quantifying the direct and indirect impact of variables on one another.

\subsection{Sample}

The population in this study includes 2-to-5-star Spanish hotel establishments in the Official Spain Hotel Guide, published by Turespaña.

Table 1 - Field work file

\begin{tabular}{|l|rr|}
\hline Sample size & & 3,900 \\
\hline Field & $\begin{array}{c}\text { 2-to-5-star Spanish hotel establishments in Turespaña's } \\
\text { Official Hotel Guide }\end{array}$ & 102 \\
\hline Obtained answers & & Simple random \\
\hline Sampling procedure & & $5.17 \%$ \\
\hline Confidence level & & $9.58 \%$ \\
\hline Answer rate & & $\mathrm{p}=50 \% ; \alpha=0.05$ \\
\hline Sampling error & & January-June 2014 \\
\hline Field work & & \\
\hline
\end{tabular}

Table 2 shows the most relevant data of the descriptive features of the data from the hotel establishments under study. 
Table 2 - Obtained answers

\begin{tabular}{|c|c|c|c|}
\hline Hotel rating & & $\begin{array}{l}\text { Position of the person } \\
\text { surveyed }\end{array}$ & \\
\hline 2 stars & $20.94 \%$ & \multirow{4}{*}{ Hotel director/deputy } & \multirow{4}{*}{$100 \%$} \\
\hline 3 stars & $34.88 \%$ & & \\
\hline 4 stars & $9.30 \%$ & & \\
\hline 5 stars & $34.88 \%$ & & \\
\hline Establishment age & & Establishment size & \\
\hline$>25$ years & $25.58 \%$ & Small & $41.86 \%$ \\
\hline $10-25$ years & $30.23 \%$ & Medium & $41.86 \%$ \\
\hline$<10$ years & $44.19 \%$ & Large & $16.28 \%$ \\
\hline $\begin{array}{l}\text { Part of a hotel } \\
\text { chain? }\end{array}$ & & Location & \\
\hline Yes & $48.83 \%$ & Town & $97.67 \%$ \\
\hline No & $51.17 \%$ & Rural & $2.33 \%$ \\
\hline
\end{tabular}

\subsection{Variable measurement}

Entrepreneurial orientation and hotel establishment performance have been defined as latent variables of formative kind, since they are two complex-nature constructs composed by very different dimensions (Diamantopoulos \& Winklhofer, 2001; Jarvis et al., 2003; MacKenzie et al., 2005). ${ }^{2}$

To measure entrepreneurial orientation, 9 items were used according to the scale proposed by Miller (1983), modified by Covin \& Slevin (1989) and Covin \& Miller (2014), and used by Balabanis \& Katsikeas (2004); Dimitratos et al. (2004); Zhou (2007); Kuivalainen et al. (2007, 2010); Etchebarne et al. (2010); Sundqvist et al. (2012); Zhang et al. (2012), and Covin \& Miller (2014).

To measure hotel establishment performance, we used the 7-item scale proposed by Camisón \& Villar-López (2010) and used by García-Olaveri \& Huerta (2012), Luengo \& Obeso (2013), and Miguel-Dávila \& Martín-Sánchez (2014).

\section{4.- Results and Discussion}

For data interpretation and analysis, a PLS structural equation model (SEM) was used with software package SMARTPLS 3.1.9. PLS is particularly interesting in this study for multiple reasons. Following Ringle, Wende \& Will (2005), and Gefen, Rigdon \& Straub (2011), the choice of PLS is considered more appropriate in the first stages of theory development, when research is focused on the prediction of one or more dependent variables. Our study is aimed at determining how entrepreneurial orientation and/or its dimensions determine hotel establishment performance level. Besides, this method is especially useful when researchers include scales previously tested and validated in other studies: in this case, entrepreneurial orientation and its dimensions had already been tested in numerous empirical studies. Finally, relatively small sample size makes PLS a suitable method. Following Reinartz, Haenlein \& Henseler (2009, p. 334): "PLS must be the method to choose in all

\footnotetext{
${ }^{2}$ In the case of performance, quantitative and qualitative dimensions are combined.
} 
situations in which the number of observations is below 250". Therefore, the choice of PLS is fully justified by the reduced amount of observable data and research objectives themselves (Barroso et al., 2005).

Although PLS simultaneously estimates the parameters for the measurement and the structural models, analyses must be completed in two stages: measurement model evaluation and structural model evaluation. This procedure assures valid and reliable scales prior to testing hypotheses.

\subsection{Measurement model evaluation}

The first thing we shall check is the loading of the dimensions that integrate entrepreneurial orientation, taken as a second-order variable. Following previous approaches, entrepreneurial orientation was conceived as a 3D multidimensional construct (Miller, 1983; Covin \& Slevin, 1989; Covin \& Miller, 2014): innovation, pro-activeness, and risk-taking. PLS allows no direct inclusion of second-order constructs, so this kind of constructs was created by means of a 2-step approximation method (Wetzels, Odekerken-Schroder \& Van Oppen, 2009). This procedure implies that a first stage comprises the factors that constitute entrepreneurial orientation in the model as a first-order construct. This first estimation allows obtaining the values of the latent variable 'Entrepreneurial Orientation'. The second stage estimates the second-order model using the values of the latent variable's first-order factors as input variables.

Following recommendations by Roldán \& Sánchez-Franco (2012), once the second-order model had been constructed, the measurement model was evaluated. Table 3 shows the parameters associated to measurement model evaluation. As it can be observed in reflective scales, factor loadings do not exceed the 0.7 recommended in literature (Carmines \& Zeller, 1979). However, some authors state that this 0.7 threshold should not be considered so rigidly in second-order variables, as it may actually be around 0.5 (Barclay, Higgins \& Thompson, 1995; Chin, 1998). Moreover, composite reliability and average variance extracted (AVE) values exceed the recommended limits of 0.7 and 0.5 , respectively (Nunnally, 1978; Fornell \& Larcker, 1981). The obtained values support the convergent validity of the reflective scales considered in the present study.

Tabla 3 - Measurement model evaluation

\begin{tabular}{|c|r|r|r|r|r|}
\hline $\begin{array}{c}\text { Construct/ } \\
\text { dimension/indicator }\end{array}$ & VIF & Weight & $\begin{array}{c}\text { Factor } \\
\text { loading } \\
\left(\boldsymbol{\rho}_{\mathbf{c}}\right)\end{array}$ & $\begin{array}{c}\text { Composite } \\
\text { reliability }\end{array}$ & AVE \\
\hline $\begin{array}{c}\text { ENTREPRENEURI } \\
\text { AL ORIENTATION } \\
\text { (second-order formative } \\
\text { construct) }\end{array}$ & & & & & n. a. \\
\hline $\begin{array}{c}\text { INNOVATION } \\
\text { (first-order reflective } \\
\text { construct) }\end{array}$ & 1.052 & 0.700 & & 0.907 & 0.764 \\
\hline $\begin{array}{l}\text { INN1 INN2 } \\
\text { INN3 reflective }\end{array}$ & 2.563 & 0.564 & 0.869 & & \\
\hline $\begin{array}{l}\text { PROACTIVENESS } \\
\text { (first-order rof }\end{array}$ & & & & \\
\hline
\end{tabular}




\begin{tabular}{|c|c|c|c|c|c|}
\hline construct) & & & & & \\
\hline PRO-ACT1 & & & 0.707 & & \\
\hline PRO-ACT2 & & & 0.917 & & \\
\hline PRO-ACT3 & & & 0.830 & & \\
\hline RISKTAKING (first- & & & & & \\
\hline $\begin{array}{l}\text { order } \\
\text { construct) }\end{array}$ & 2.637 & 0.526 & & 0.721 & 0.561 \\
\hline RISK1 & & & 0.577 & & \\
\hline RISK2 & & & 0.668 & & \\
\hline RISK3 & & & 0.721 & & \\
\hline $\begin{array}{l}\text { PERFORMANCE } \\
\text { (second-order } \\
\text { formative construct) }\end{array}$ & & & & n. a. & n. a. \\
\hline $\begin{array}{l}\text { ECONOMIC } \\
\text { PERFORMANCE } \\
\text { (first-order reflective } \\
\text { construct) }\end{array}$ & 1.365 & 0.597 & & 0.756 & 0.517 \\
\hline EC PER1 & & & 0.617 & & \\
\hline EC PER2 & & & 0.701 & & \\
\hline EC PER3 & & & 0.754 & & \\
\hline $\begin{array}{l}\text { SATISFACTION } \\
\text { PERFORMANCE } \\
\text { (first-order reflective } \\
\text { construct) }\end{array}$ & 1.771 & 0.899 & & 0.881 & 0.652 \\
\hline SAT PER1 & & & 0.826 & & \\
\hline SAT PER2 & & & 0.894 & & \\
\hline SAT PER3 & & & 0.840 & & \\
\hline SAT PER4 & & & 0.822 & & \\
\hline
\end{tabular}

Diamantopoulos' (2008) recommendations were taken into account in formative scale validation ('Entrepreneurial Orientation' and 'Performance'). No indicator could be eliminated, as they were considered to bear relevant information. Absence of multicollinearity was assured by means of the variance inflation factor (VIF), which was below 5 (Diamantopoulos \& Wilklhofer, 2001).

\subsection{Structural model analysis}

Once the measurement model's convergent and discriminant validity had been proven, the relationships between the different variables were tested by bootstrapping (1000 subsamples). This structural model was examined through the significance of $\beta$ coefficients through the observation of the dependant variables' $R^{2}$ values. In this sense, all $\beta$ coefficients proved significant at $1 \%$.

The hypotheses were confirmed through the interpretation of the coefficients of the structural trajectories:

1 - Entrepreneurial orientation has a significant impact on performance $(\beta=0.590 ; \mathrm{t}=$ $5.385)$

2 - Innovation has a positive impact on performance $(\beta=0.447 ; \mathrm{t}=5.120)$, 
3 - Pro-activeness has a positive impact on hotel establishment performance $(\beta=0.391 ; \mathrm{t}$ $=3.934)$, and, finally,

4 - Risk-taking has a positive impact on hotel establishment performance $(\beta=0.364 ; \mathrm{t}=$ 3.269).

Table 4 - Structural model results

\begin{tabular}{|c|c|c|c|}
\hline Hypothesis & B & t-value & $\mathbf{R}^{2}$ \\
\hline $\mathrm{H}_{1}: \mathrm{EO} \rightarrow \mathrm{D}$ & 0.590 & $5.385^{*}$ & 0.348 \\
\hline $\mathrm{H}_{2}: \mathrm{I} \rightarrow \mathrm{D}$ & 0.447 & $5.120^{*}$ & 0.200 \\
\hline $\mathrm{H}_{3}: \mathrm{PROAC} \rightarrow \mathrm{D}$ & 0.391 & $3.934 *$ & 0.153 \\
\hline $\mathrm{H}_{4}: \mathrm{ASUN} \rightarrow \mathrm{D}$ & 0.364 & $3.269^{*}$ & 0.132 \\
\hline
\end{tabular}

Note: $* \mathrm{p}<0.01$.

Finally, entrepreneurial orientation explains $34.8 \%$ of the variance in hotel establishment performance, while innovation, pro-activeness and risk-taking explain 20, 15.3 and 13.2\%, respectively. According to this result, the integrated approach, as suggested at the beginning of the present work, has greater impact on hotel establishment performance than each of its dimensions taken independently.

\section{Conclusions, Limitations and Future Research Lines}

The results of this work deal with the relationship between entrepreneurial orientation and hotel establishment performance, on one hand, and between each of the three dimensions that shape entrepreneurial orientation (namely, innovation, pro-activeness and risk-taking) and hotel establishment performance, on the other hand. These results corroborate the proposed theoretical model, which was tested on a sample of 102 hotel establishments located in Spain. Results provide relevant implications for researchers and professionals related with hotel management.

Results confirm that hotel establishment performance depends on entrepreneurial orientation, which explains $34.8 \%$ of the former's variance, in agreement with previous researches (Zahra \& Covin, 1995; Tajeddini, 2010; Tang \& Tang, 2012). On the other hand, if the individual effect of each individual dimension is analysed, all three can be observed to have a positive impact on hotel establishment performance: innovation, pro-activeness and risk-taking explain $20,15.3$ and $13.2 \%$ of performance variance. Therefore, innovation is the most relevant dimension in entrepreneurship orientation, as suggested in other previous researches (Sandvik, Duhan \& Sandvik, 2014; Tajeddini \& Trueman, 2014).

Finally, the most relevant conclusion of the present work is that the joint impact of these three dimensions on hotel establishment performance exceeds the individual reach of each of the considered dimensions. In short, the thesis proposed by Miller (1983), Covin \& Slevin (1989), and Covin \& Miller (2014), among others, is corroborated.

This work has its limitations. Firstly, only objective measures were used in the measurement of entrepreneurial orientation and its dimensions. Secondly, this is a transversal study, whereas longitudinal study is needed to evaluate the direction of causality in the studied issues. Thirdly, the model should include the effect of internal and external variables that may moderate the relationship between entrepreneurial orientation and performance. Fourthly, it would be advisable to supplement this research with qualitative approaches, 
which would allow identifying further factors that could be considered in this relationship. Last, it would be particularly interesting to obtain information from several informers within the same establishment.

\section{References}

Arzubiaga, U. et al. (2012): "La medición de la orientación emprendedora en las empresas familiares: una revisión crítica de la literatura", Revista de Empresa Familiar, no 2(2), $57-71$.

Balabanis, G. \& Katsikea, E. (2004): “Being an entrepreneurial exporter: doit pay?", International Business Review, $\mathrm{n}^{\mathrm{o}}$ 12, 232-252.

Barclay, D., Higgins, C., \& Thompson, R. (1995): The partial least squares (PLS) approach to causal modeling: Personal computer adoption and use as an illustration. Technology studies, 2(2), 285-309.

Basso, O. et al. (2009): Entrepreneurial orientation: the making of a concept, International Journal of entrepreneurship and innovation, $n^{\circ} 10,313-321$.

Berthon, P., Mac Hulbert, J., \& Pitt, L. (2004): Innovation or customer orientation? An empirical investigation. European Journal of Marketing, 38(9/10), 1065-1090.

Camisón, C., \& Villar-López, A. (2010): Análisis del papel mediador de las capacidades de innovacion tecnológica en la relación entre la forma organizativa flexible y el desempeño organizativo. Cuadernos de Economía y Dirección de la Empresa, 13(45), 115-143.

Chandra, A. et al. (2007): Business Incubators in China: A Financial Services Perspective, Asia Pacific Business Review, $\mathrm{n}^{\circ} 13$ (1), 79-94.

Covin, J. G. \& Lumpkin, G.T. (2011): Entrepreneurial orientation theory and research: Reflections on a needed construct, Entrepreneurship Theory and Practice, $\mathrm{n}^{\mathrm{o}} 35(5)$, pp. 855-872.

Covin, J. G., \& Miller, D. (2014). International entrepreneurial orientation: Conceptual considerations, research themes, measurement issues, and future research directions. Entrepreneurship Theory and Practice, 38(1), 11-44.

Covin, J. G. \& Slevin, D. P. (1991): “A conceptual model of entrepreneurship as firm behavior", Entrepreneurship Theory and Practice, $\mathrm{n}^{\mathrm{0}} 16,7-25$.

Covin J. G. \& Wales, W. J. (2012): "The measurement of entrepreneurial orientation. entrepreneurship", Entrepreneurship Theory and Practice, $\mathrm{n}^{\circ} 36,677-702$.

Dai, L. et al. (2013): Entrepreneurial orientation and international scope: The differential roles of innovativeness, proactiveness, and risk-taking. Journal of Business Venturing.

Dijkstra, T. K.; Henseler, J. (2015). Consistent and asymptotically normal PLS estimators for linear structural equations. Computational Statistics \& Data Analysis, 81(1), 10-23.

Dillman, D. A. (2000): Mail and internet surveys: The tailored design method (Vol. 2). New York: Wiley.

Dimitratos, P. \& Plakoyiannaki, E. (2003): "Theoretical foundations of an international entrepreneurial culture", Journal of International Entrepreneurship, $\mathrm{n}^{\mathrm{0}} 1,187-215$.

Dimitratos, P., Lioukas, S. \& Carter,S. (2004): The Relationship Between Entrepreneurship and International Performance: The Importance of Domestic Environment, International Business Review 13 (1), 19-41.

Etchebarne, M. S. et. al. (2010): "El impacto de la orientación emprendedora en el desempeño exportador de la firma", Esic Market, vol. 137, 165-220.

Fornell, C. et al. (1990): "The cooperative venture formation process: a latent variable structural modelling approach”, Management Science, $\mathrm{n}^{\mathrm{o}}$ 36, 1246-1255. 
Fraj, E., Matute, J., \& Melero, I. (2015): Environmental strategies and organizational competitiveness in the hotel industry: The role of learning and innovation as determinants of environmental success. Tourism Management, 46, 30-42.

García Olaverra, C \& Huerta, E. (2012): Why do Some Companies Adopt Advanced Management Systems? The Spanish Case, Management Research, 10 (2), pp. 99-124.

Gefen, D., Straub, D. W., \& Rigdon, E. E. (2011): An update and extension to SEM guidelines for admnistrative and social science research. Management Information Systems Quarterly, 35(2), iii-xiv.

Godwin Ahimbisibwe M. \& Abaho E. (2013): Export entrepreneurial orientation and export performance of SMEs in Uganda, Global Advanced Research Journal of Management and Business Studies, ${ }^{\circ}$ 2(1), 56-62.

Henseler, J., Ringle, C. M., \& Sarstedt, M. 2015. A new criterion for assessing discriminant validity in variance-based structural equation modeling. Journal of the Academy of Marketing Science, 43(1), 115-135.

Hernández Perlines, F. (2014): Orientación emprendedora de las cooperativas agroalimentarias con actividad exportadora. CIRIEC-España, Revista de Economía Pública, Social y Cooperativa, (80), 28-55.

Hult, G. T. M. et al. (2003): The role of entrepreneurship in building cultural competitiveness in different organizational types, Journal of Management, $\mathrm{n}^{\circ}$ 29(3), pp. 401-426.

Ireland, R. D., Kuratko, D. F., \& Morris, M. H. (2006): A health audit for corporate entrepreneurship: innovation at all levels: part I. Journal of Business Strategy, 27(1), $10-17$.

Jogaratnam, G. \& Tse, E. C. Y. (2006): Entrepreneurial orientation and the structuring of organizations: performance evidence from the Asian hotel industry. International Journal of Contemporary Hospitality Management, 18(6), 454-468.

Keh, H. T., Nguyen, T. T. M., \& Ng, H. P. (2007): The effects of entrepreneurial orientation and marketing information on the performance of SMEs. Journal of Business Venturing, 22(4), 592-611.

Knight, G. A. (1997): "Cross-cultural reliability and validity of a scale to measure firm entrepreneurial orientation", Journal of Business Venturing, 12(3), 213-225.

Kreiser, P. et al. (2013): "Disaggregating Entrepreneurial Orientation: The Non-Linear Impact of Innovativeness, Proactiveness and Risk-Taking on SME Performance," Small Business Economics, 40 (2), pp. 1-19.

Kuivalainen, O. et al. (2010): "Entrepreneurial orientation and international performance: A contingent approach", in Pla-Barber, J. \& Alegre, J. (2010): Reshaping the Boundaries of the Firm in an Era of Global Interdependence (Progress In International Business Research, Volume 5), Emerald Group Publishing Limited.

Luengo, M. J. \& Obeso, M. (2013). El Efecto de la Triple Hélice en los Resultados de Innovación. RAE-Revista de Administração de Empresas, 53(4), 388-399.

Ma, Y. J. et al. (2012): The Effects Entrepreneurship and Market Orientation on Social Performance of Social Enterprise, Int Conf Econ Market Manager, 28, pp. 60-65.

McGrath, R. G. (2001): Exploratory learning, innovative capacity, and managerial oversight. Academy of Management Journal, 44(1), 118-131.

Miller, D. (1983): "The correlates of entrepreneurship in three types of firms", Management Science, 29, 770-791.

Naldi, L., Nordqvist, M., Sjöberg, K., \& Wiklund, J. (2007): Entrepreneurial orientation, risk taking, and performance in family firms. Family Business Review, 20(1), 33-47.

Rauch, A. et al. (2009): "Entrepreneurial orientation and business performance: an assessment of past research and suggestions for the future", Entrepreneurship Theory and Practice, 33, 761-787. 
Reinartz, W., Haenlein, M., \& Henseler, J. (2009): An empirical comparison of the efficacy of covariance-based and variance-based SEM. International Journal of research in Marketing, 26(4), 332-344.

Ringle, C. M., Sarstedt, M., Schlittgen, R., \& Taylor, C. R. (2013): PLS path modeling and evolutionary segmentation. Journal of Business Research, 66(9), 1318-1324.

Rodrigo-Alarcón, J. et al (2013): Efectividad de la orientación emprendedora: el papel del capital social y las capacidades. Investigaciones Europeas de Dirección y Economía de la Empresa, 19 (4).

Roldán, J. L., \& Sánchez-Franco, M. J. (2012): Variance-based structural equation modeling: guidelines for using partial least squares in information systems research. Research methodologies, innovations and philosophies in software systems engineering and information systems, 193-221.

Sundqvist, S. et al (2012): Kirznerian and Schumpeterian entrepreneurial- oriented behavior in turbulent export markets, International Marketing Review, 29(2), pp. 203-219.

Tajeddini, K. (2010): Effect of customer orientation and entrepreneurial orientation on innovativeness: Evidence from the hotel industry in Switzerland, Tourism Management, 31(2), 221-231.

Tajeddini, K., \& Trueman, M. (2008): The potential for innovativeness: a tale of the Swiss watch industry. Journal of Marketing Management, 24(1-2), 169-184.

Tajeddini, K., \& Trueman, M. (2014): Perceptions of innovativeness among Iranian hotel managers. Journal of Hospitality and Tourism Technology, 5(1), 62-77.

Tang, J. et al. (2012): Entrepreneurial alertness in the pursuit of new opportunities. Journal of Business Venturing, 27(1), pp. 77-94.

Thoumrungroje, A., \& Racela, O. (2013): The contingent role of customer orientation and entrepreneurial orientation on product innovation and performance. Journal of Strategic Marketing, 21(2), pp. 140-159.

Tsang, E. W. K. (2002): Acquiring knowledge by foreign partners from international joint ventures in a transition economy: learning by doing and learning myopia, Strategic Management Journal, 23, (9), pp. 835-854.

Wetzels, M., Odekerken-Schroder, G., \& Van Oppen, C. (2009): Using PLS path modeling for assessing hierarchical construct models: guidelines and empirical illustration. Management Information Systems Quarterly, 33(1), 11, 177-195.

Wiklund, J., \& Shepherd, D. (2005): Entrepreneurial orientation and small business performance: a configurational approach, Journal of Business Venturing, 20, 71-91.

Zhang, X.et al. (2012): Entrepreneurial orientation, social capital, and the internationalization of SMEs: Evidence from China, Thunderbird International Business Review, 54(2), pp. 195-210.

Zhou, L. (2007): The effects of entrepreneurial proclivity and foreign market knowledge on early internationalization, Journal of World Business, 42 (3), pp. 281-293. 